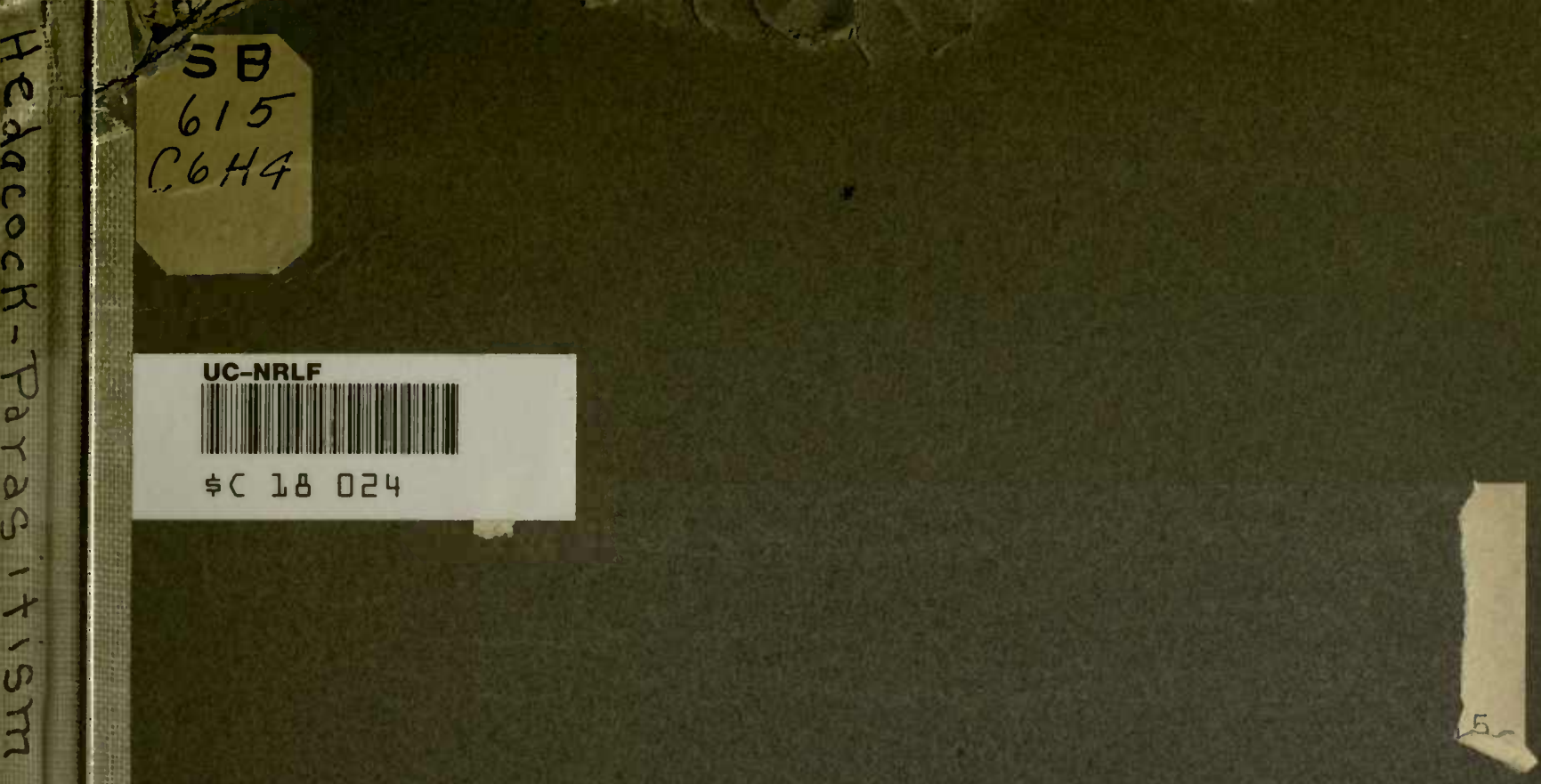




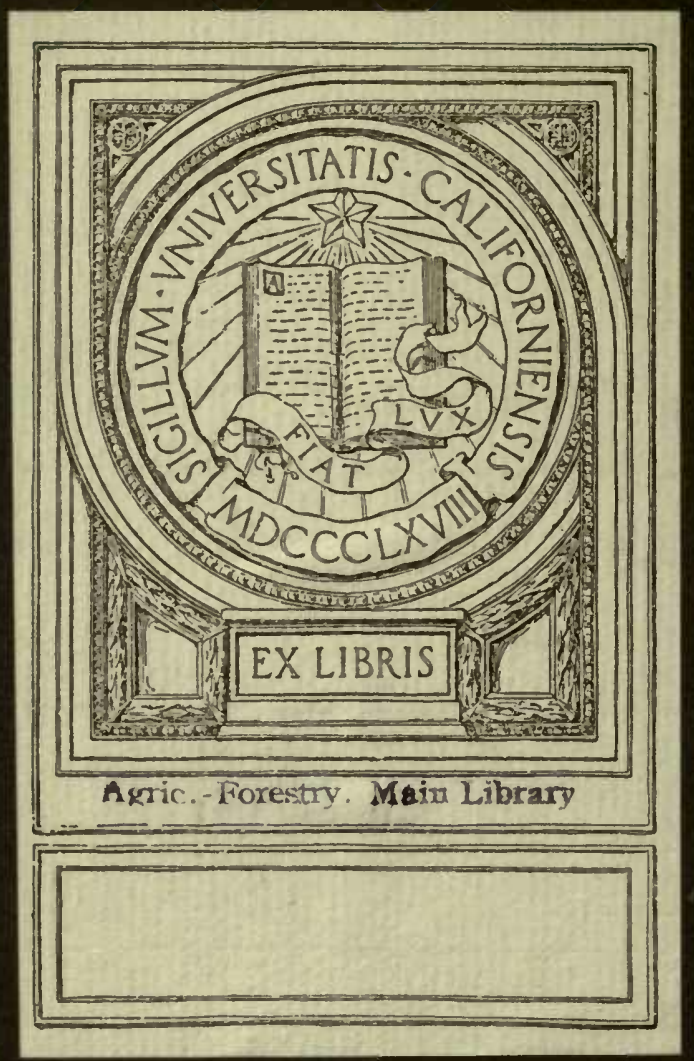




\begin{abstract}
REPRINT FROM

\section{JOTRNAL OF AGRCULTIRAL RESEARCH} DEPARTMENT OF AGRICULTURE
\end{abstract}

VOL. V WASHNGTON, D. C., OCTOBER I8, I9I5

No. 3

PARASITISM OF COMANDRA UMBELIATA

BY GEORGE G. HFDGCOCK 
-2.

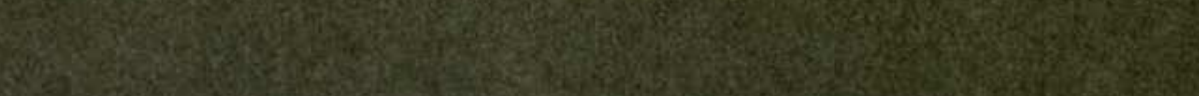
15.

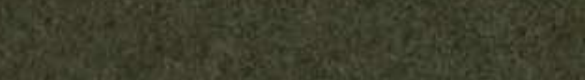

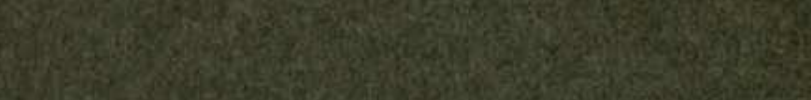

20 (x)

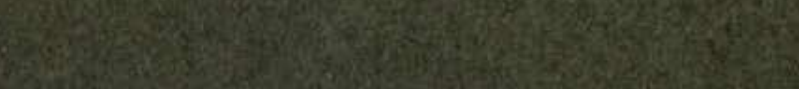

(4)

(5)

6ifing

कर

wost

and 
Agric.-Forestry. Main Library

\title{
PARASITISM OF COMANDRA UMBELLATA
}

\author{
By George Grant Hedgcock, \\ Pathologist, Investigations in Forest Pathology, \\ Bureau of Plant Industry
}

One of the most important and most injurious of the stem or blister rusts occurring on pines is Peridermium pyriforme Peck, which attacks Pinus (murrayana) contorta Loud., $P$. ponderosa Laws., and $P$. ponderosa scopulorum Engelm. in the western United States, $P$. divaricata Du Mont de Cours. in the Northern States, and P. pungens Michx. and P. rigida Mill. in the Northwestern States. Peridermium pyriforme is a heterœcious rust and is dependent for its existence upon its alternate, or summer, stage, which occurs on species of Comandra.

The problem of the eradication of this important rust being so intimately associated with plants of Comandra spp. led the writer to investigate their manner of growth and means of propagation. It was found that the plants of at least two species, $C$. pallida A. DC. and C. umbellata (L.) Nutt., have apparently become largely dependent on parasitism for their continued existence. The other two North American species, C. livida Richards, and C. richardsiana Fernald, resemble the former species in appearance and habit and are probably equally parasitic in their nature.

The writer has carefully examined the root system of living plants of both $C$. umbellata and $C$. pallida, but only of dried specimens of the other two species. The former have long underground rootstocks which bear here and there small roots or rootlets usually less than 5 inches in length. These rootlets branch sparsely and are nearly always attached to the roots or underground stems of other species of plants. At the point of attachment there is formed by the root of Comandra spp. a nearly hemispherical disk or holdfast. This holdfast is either superficial or slightly embedded in the cambiun layer of tissues of the host, but does not send out haustoria, as is the case in species of Razoumofskya on the limbs and trunks of coniferous trees. The chief function of the roots of Comandra spp. appears to be that of attachment to host plants for the purpose of obtaining nourishment and a water supply. Plants of Comandra spp. frequent dry, rocky soils, which often have a low water content.

Plants of all these species of Comandra bear leaves; and although attached as parasites to the roots of other plants, they are not entirely dependent upon their host plants for organic compounds, since they are able to further elaborate these compounds in the liquids received from 
their hosts. In this respect their development is similar to that of plants of species of Phoradendron.

Both $C$. umbellata and $C$. pallida very commonly are associated with and parasitic upon species of Vaccinium, but are not at all dependent upon this genus for host plants. This has especially been noted in the case of $C$. pallida in the States of Colorado, Montana, Nebraska, South Dakota, and Wyoming, and in C. umbellala in the States of Connecticut, Maryland, Michigan, Minnesota, New Jersey, New York, Pennsylvania, Vermont, Virginia, and Wisconsin, and the District of Columbia. Plants of both species are parasitic upon a great variety of plants belonging to widely different sections of the Spermatophyta. No attachment to plants of any member of the Pteridophyta has been noted.

C. umbellata has been found by the writer as a parasite on the roots of the following species of plants in the Eastern States:

Acer rubrum $L$.

Achillea millefolium $\mathrm{L}$.

Andropogon virginicus L.

Angelica villosa (Walt.) B. S. P.

Antennaria plantaginifolia (L.) Richards. Aster ericoides L.

Aster macrophyllus I.

Aster patens Ait.

Aster undulatus L.

Baptisia tinctoria (L.) $\mathrm{Br}$.

Betula nigra L.

Betula populifolia Marsh.

Carex sp.

Castanea dentata (Marsh.) Borkh.

Chimaphila umbellata (L.) Nutt.

Chrysopsis mariana (L.) Nutt.

Comptonia peregrina (L.) Coulter.

Danthonia compressa Austin.

Fragaria americana (Porter) Britton.

Fragaria virginiana Duchesne.

Gaylussacia frondosa (L.) T. and G.

Hieracium venosum $\mathrm{L}$.

Ionactis linariifolius (I.) Greene.

Lespedeza violacea (L.) Pers.

Lysimachia quadrifolia $\mathbf{L}$.

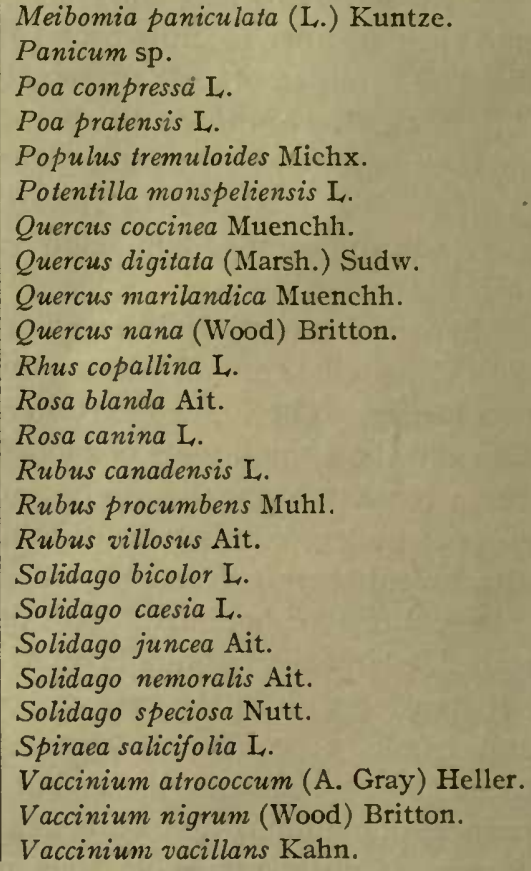

In addition to the foregoing and incomplete list there must be added at least three unidentified species of grasses.

During the last three years a number of attempts, with varying success, have been made at Washington, D. C., to grow plants of $C$. umbellata and $C$. pallida, both by germinating the seed and by transplanting rootstocks to beds and pots in greenhouses. In every case where living rootstocks unattached to host plants have been transplanted to pots or 
beds without the host plants present, little or no growth on the part of the plants of Comandra spp. has taken place, and the plants eventually died. Successful results in growing these species have been accomplished by only two methods: First, by transplanting sods containing the plants of Comandra spp. from out of doors to the greenhouse without breaking the attachments of the roots of the parasite to those of the host; second, by planting seed in flats in the fall out of doors and germinating them in the presence of the roots of host plants after exposing the seeds to freezing temperatures by allowing the flats to remain out of doors all winter.

Dr. E. P. Meinecke, of the Office of Forest Pathology, reports by letter that he has three plants of $C$. umbellata raised from seed sown in 1913 , which remained dormant till 1915, when they germinated and grew without any host plant. These plants were 5 inches high on July 17 , 1915. This is positive proof that this species of Comandra can live without parasitism if necessary. It remains to be seen whether these plants will continue to grow indefinitely without the presence of host plants.

The results from our experiments indicate that when the rootstocks of plants of Comandra spp. are broken entirely loose from their root attachment to host plants they usually die through an inability to reattach themselves. These new data on a subject which apparently has not been previously investigated indicate a greater degree of parasitism in species of Comandra than has hitherto been suspected, and will render more obvious the desirability of the destruction of plants of Comandra spp. in the vicinity of forest-tree nurseries. 

Fint

ints

(20.7.

Pench

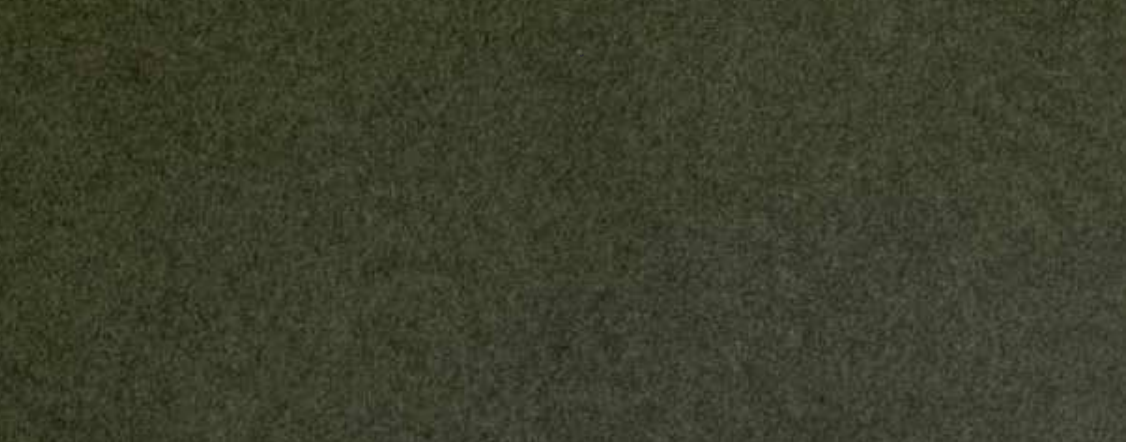

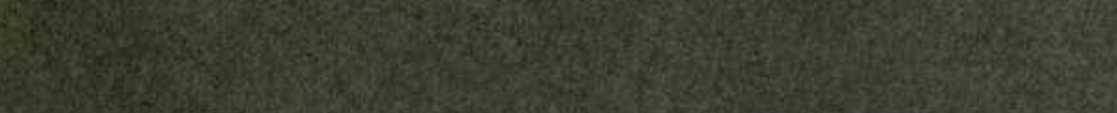
3.7.

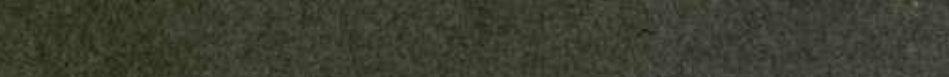
7.

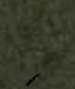

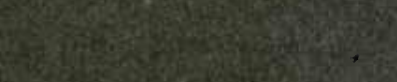
din-

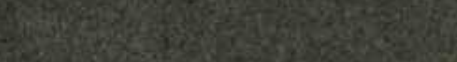

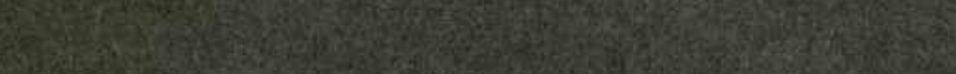
Now the 20.

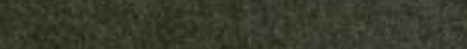
mans

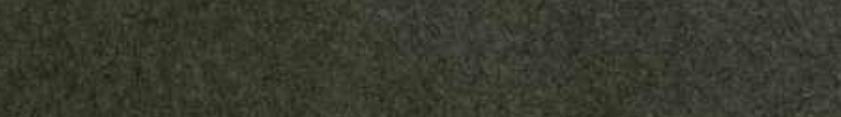
Lin 


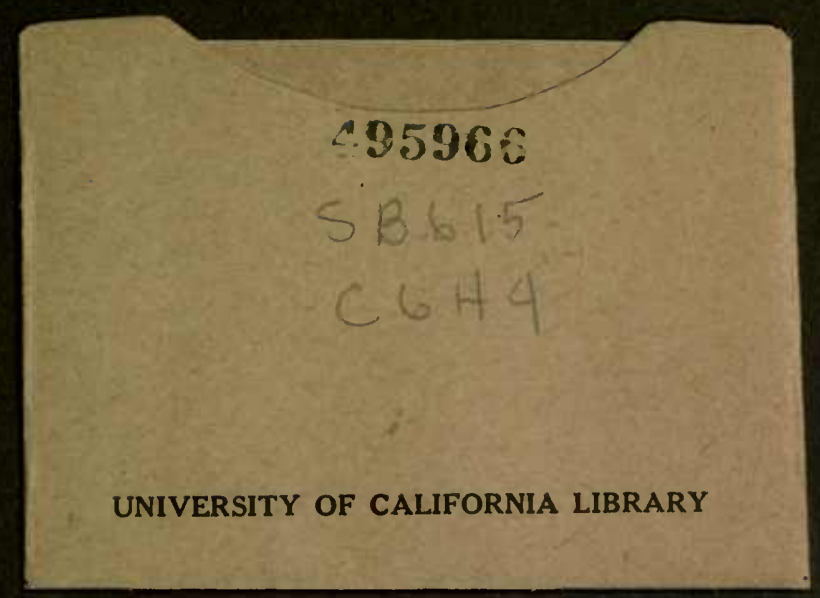


